\title{
STANDING TO SUE IN HISTORIC PRESERVATION CASES
}

\author{
John W. VardaMaAN, JR.*
}

Despite the vast amount of literature on the subject, ${ }^{1}$ it is perhaps appropriate that in a symposium on environmental or conservation law or on such a closely related field as historic preservation there be a paper on standing to sue. Five years ago it was unclear whether private individuals or organizations had standing to seek judicial review under statutes such as the Ig66 amendment to the Historic Sites Act or section $4(f)$ of the Department of Transportation $\mathrm{Act}^{3}$ if they could claim no economic injury or if there were no explicit statutory provisions granting standing. The problem was clouded by doubts as to whether standing requirements were constitutionally required and whether standing was concerned only with the identification of a proper party to bring an action or whether it involved the entire gamut of problems related to the justiciability of various types of controversies. Thus, standing has been aptly described as a "complicated specialty of federal jurisdiction ...."." and as "one of the "most amorphous [concepts] in the entire domain of public law." "'

Times have changed, however, and recently courts have not only simplified standing tests, but they have expanded the categories of persons permitted to seek judicial review under federal statutes protecting the environment. Those precedents are directly applicable to cases brought under the recent federal statutes designed to protect historic sites and areas, and have rendered standing one of the less important problems in environmental and conservation law. Even if it is true, as Mr. Justice Douglas said, that "[g]eneralizations about standing to sue are largely worthless as such," one can, with reasonable certainty, venture that an organization which has been active in the preservation of historic sites and areas and which prior to litigation has demonstrated an active interest in the particular subject matter of the litigation will be held to have standing to seek judicial review under federal statutes concerned with historic preservation. Subsidiary questions will, of course, arise. In discussing standing to sue, one is driven to oversimplification on the one

- Member, Williams, Connolly and Califano, Washington, D.C.

${ }^{2}$ See, e.g., 3 K. Davis, AdMinistrative LaW $\$ 22$ (x958, Supp. r970); L. JafFe, Judicial Control op Aoministrative Action 459-545 (1965); Berger, Standing to Sue in Pablic Actions: Is it a Constitutional Requirement?, 78 YALE L.J. 8r6 (1969); Davis, The Liberalized Law of Standing, 37 U. CHr. L. Rev. 450 (I970); Jaffe, Standing Again, 84 HARv. L. REv. 633 (1971); Jaffe, The Citizen as Litigant in Public Actions: The Non-Hohfeldian or Ideological Plaintiff, II6 U. PA. L. REv. I033 (1968).

216 U.S.C. $\$ \$ 470-470 \mathrm{~m}$ (1970).

${ }^{3} 49$ U.S.C. $\$ 1653(f)$ (I970).

¿United States ex rel. Chapman v. FPC, 345 U.S. 153, 156 (1953).

${ }^{5}$ Flast v. Cohen, 392 U.S. 83, 99 (1968), quoting statement of Professor Paul R. Freund in Hearings on S. 2097 Before the Subcomm. on Constitutional Rights of the Senate Comm. on the Judiciary, 8gth Cong., 2d Sess. 498 (1966).

${ }^{8}$ Data Processing Service v. Camp, 397 U.S. 150, I5I (1970). 
hand or to technical, scholastic arguments on the other. The courts are now taking the former approach, and for all those interested in the burgeoning fields of environmental and conservation litigation, it is a welcome development.

\section{I}

\section{Standing in Environmental Cases}

The first significant decision in the environmental field was Scenic Hudson Preservation Conference v. FPC. ${ }^{7}$ In that case the Scenic Hudson Preservation Conference, made up of a number of conservation organizations, and three towns petitioned the Court of Appeals for the Second Circuit to set aside an order of the Federal Power Commission permitting Consolidated Edison to construct a massive hydroelectric storage project at Storm King Mountain on the Hudson River. The order was challenged on the ground that the Commission had failed to consider, as required by statute, a number of alternatives which would have lessened the impact of the project on the scenic and historic areas surrounding Storm King Mountain. The court held that all of the petitioners had standing under the provision of the Federal Power Act ${ }^{8}$ which permitted a party "aggrieved" by an FPC order to seek review in a Court of Appeals. Rejecting the Commission's argument that only those parties with economic interests had standing to seek review, the court held that

In order to insure that the Federal Power Commission will adequately protect the public interest in the aesthetic, conservational, and recreational aspects of power development, those who by their activities and conduct have exhibited a special interest in such areas, must be held to be included in the class of "aggrieved" parties under $\S 3^{1} 3(b) .^{9}$

The court buttressed its holding by noting that the parties also had economic interests at stake. The tax revenues of the towns would have decreased as a result of the decrease in value of the property in the area. One of the conservation groups had seventeen miles of trails in the area, portions of which would have been inundated. The economic interests alluded to by the court, however, hardly seem essential to the holding that these parties had standing, for the court permitted the conservation group a remedy having no connection to the injury it allegedly suffered. This plaintiff not only was allowed to challenge the flooding of the trailways but was also permitted to compel consideration of the desirability of underground power lines and fish-protecting devices.

A second major decision, coming only months after Scenic Hudson, was Office of Communication of the United Church of Christ v. FCC. ${ }^{10}$ In that case a group of individuals sought to intervene in a Federal Communications Commission proceeding to oppose renewal of a license on the basis that the station had engaged in

\footnotetext{
${ }^{7} 354$ F.2d 608 (2d Cir. 1965), cert. denied, 384 U.S. 94 I (1966).

8 I6 U.S.C. $\$ 825 l(\mathrm{~b})(\mathrm{r} 970)$.

354 F.2d at 6 r6.

${ }^{10} 359$ F.2d 994 (D.C. Cir. 1966).
} 
racial and religious discrimination in its broadcast practices. ${ }^{11}$ The sole interest which the petitioners sought to represent was that of the listening public. The FCC denied standing because the parties could not assert any economic injury or electrical interference arising from the license. The Court of Appeals for the District of Columbia reversed, holding that the Commission construed too narrowly the requirements of standing. It said:

Since the concept of standing is a practical and functional one designed to insure that only those with a genuine and legitimate interest can participate in a proceeding, we can see no reason to exclude those with such an obvious and acute concern as the listening audience. ${ }^{12}$

While recognizing the difficulty of enumerating the types of organizations or groups that should be permitted to assert the public interest, the court noted that "such community organizations as civic associations, professional societies, unions, churches, and educational institutions or associations might well be helpful to the Commission."13 These "usually concern themselves with a wide range of community problems and tend to be representatives of broad as distinguished from narrow interests, public as distinguished from private or commercial interests."14

Following Scenic Hudson and Church of Christ, the courts opened their doors to a wide range of parties in conservation and preservation cases. These included nationwide and local organizations dedicated to protecting or preserving the environment, ${ }^{15}$ ad hoc citizens' associations, ${ }^{16}$ taxpayers, ${ }^{17}$ property owners, ${ }^{18}$ townships, ${ }^{10}$

11 The petitioners only sought judicial review of the denial of their request to appear before the hearing of the agency. Therefore, unlike the other cases discussed in this article, the standing question did not concern whether the petitioners had standing to initiate judicial review of an agency action, but whether they had standing to appear before an administrative agency. In determining the standing of the petitioners, the court in Church of Christ referred to the legislative history of the applicable statute and not to the constitutional, article III question of standing. Thus, the applicability of this precedent to the question of standing in historic preservation cases may be limited. See 3 K. Davis, Administrative Law $\$ 22.08$ (1958).

12359 F.2d at 1002.

28 $I d$. at I005.

14 Id.

${ }^{16}$ See, e.g., Citizens Comm. for the Hudson Valley v. Volpe, 425 F.2d 97 (2d Cir. 1970), cert. denied, 400 U.S. 949 (I97I) (Sierra Club); Citizens to Preserve Overton Park, Inc. v. Volpe, 309 F. Supp. I189 (W.D. Tenn. 1970), aff'd 432 F.2d 1307 (6th Cir. 1970), rev'd on other grounds, 401 U.S. 402 (I97r) (Sierra Club and National Audubon Society); Environmental Defense Fund v. Hardin, 428 F.2d 1093 (D.C. Cir. 1970); Environmental Defense Fund v. United States Dep't of HEW, 428 F.2d ro83 (D.C. Cir. 1970); Wilderness Society v. Hickel, No. 928-70 (D.D.C., Apr. 23, 1970); Parker v. United States, 307 F. Supp. 685 (D. Colo. 1969) (Sierra Club); Sierra Club v. Hardin, 2 ERC 126r (E.D. Ark. I97I).

${ }^{16}$ See, e.g., D.C. Federation of Civic Ass'ns v. Airis, 39r F.2d 478 (D.C. Cir. I968); Nashville I-40 Steering Comm. v. Ellington, 387 F.2d I79 (6th Cir. 1967), cert. denied, 390 U.S. 921 (1968); Road Review League v. Boyd, 270 F. Supp. 650 (S.D.N.Y. 1967).

${ }_{17}$ See, e.g., Federation of Civic Ass'ns v. Airis, 39x F.2d 478 (D.C. Cir. I968); Citizens to Preserve Overton Park, Inc. v. Volpe, 309 F. Supp. Ix89 (W.D. Tenn. 1970), affd 432 F.2d 1307 (6th Cir. 1970), rev'd on other grounds, 401 U.S. 402 (197x).

${ }^{18}$ See, e.g., Road Review League v. Boyd, 270 F. Supp. 650 (S.D.N.Y. I967).

${ }^{18}$ See, e.g., Citizens Comm. for the Hudson Valley v. Volpe, 425 F.2d 97 (2d Cir. 1970); Road Review League v. Boyd, 270 F. Supp. 650 (S.D.N.Y. 1967). 
and other groups which a court could determine would adequately represent the public's interest in the areas concerned.

In holding that those various groups had standing, the courts have not established any absolute rules as to what is required for an organization to exhibit its "special interest" in a particular controversy. In fact, in a number of cases there has been little, if any, analysis of the various activities of the plaintiffs or the interests they represent. This is undoubtedly because in those cases the courts have been satisfied that the groups were truly adverse to the defendants, were not presenting feigned or hypothetical controversies, and in general, would shape the issues for the court. ${ }^{20}$ Where the courts have discussed the ways in which parties have exhibited their special interest they have referred to the following factors: the purposes for which organizations have been formed and the general thrust of their activities, their relationship to the general problems involved and to the specific problems involved in the litigation, ${ }^{21}$ the presence of residents of the general area affected or citizens who use the particular area, ${ }^{22}$ the extent to which the parties have participated in formal or informal administrative proceedings prior to litigation, ${ }^{23}$ and their willingness to bear the burden and expense of pursuing the litigation. ${ }^{24}$ The likelihood that a particular plaintiff will be found to have standing increases with the number of these factors which are applicable to his situation. An indication of the extent to which the doctrine of standing has been relaxed is the reliance in some cases on the plaintiff's willingness to share the expenses of litigation as a factor in determining standing. Any plaintiff, no matter how small his stake in the litigation, must be willing to encounter some burden and expense and expose himself to an assessment of costs if unsuccessful. Thus, this factor adds nothing to an analysis of whether a party has an interest that would give him standing. Yet, the courts are willing to rely on it in permitting a party to bring suit.

\section{II}

\section{The Private Attorney Generax Concept of Standing}

Both Scenic Hudson and Church of Christ, and most of the cases following those decisions, based the plaintiffs' standing on the ground that they were suing as repre-

${ }^{20}$ See Flast v. Cohen, 392 U.S. 83, 106 (1968).

${ }^{21}$ Citizens Comm. for the Hudson Valley v. Volpe, 425 F.2d 97 (2d Cir. 1970); Citizens to Preserve Overton Park, Inc. v. Volpe, 309 F. Supp. II89 (W.D. Tenn. I970), aff'd 432 F.2d I307 (6th Cir. 1970), rev'd on other grounds, 401 U.S. 402 (I97I); Environmental Defense Fund v. United States Dep't of HEW, 428 F.2d I083 (D.C. Cir. I970).

${ }^{22}$ Citizens Comm. for the Hudson Valley v. Volpe, 425 F.2d 97 (2d Cir. 1970); Road Review League v. Boyd, 270 F. Supp. 650 (S.D.N.Y. I967); Sierra Club v. Hardin, 2 ERC I26x (E.D. Ark. I97I).

${ }^{28}$ Citizens Comm. for the Hudson Valley v. Volpe, 425 F.2d 97 (2d Cir. 1970); Scenic Hudson Preservation Conf, v. FPC, 354 F.2d 608 (2d Cir. I965), cert. denied, 384 U.S. 94 I (1966); Citizens to Preserve Overton Park, Inc. v. Volpe, 309 F. Supp. 1189 (W.D. Tenn. 1970), aff'd 432 F.2d 1307 (6th Cir. 1970), rev'd on other grounds, 401 U.S. 402 (197I).

st Citizens Comm. for the Hudson Valley v. Volpe, 425 F.2d 97 (2d Cir. I970); Office of Communication of the United Church of Christ v. FCC, 359 F.2d 994 (D.C. Cir. Ig66). 
sentatives of the general public-as private attorneys general-and that the action was, in Professor Jaffe's terms, a "public action," or one in which the plaintiff was "a person who is affected no differently than any other person."25

One reason that the courts have turned to the public action or private attorney general theory is that these cases generally involve public resources or public areas; and indeed, some cases arise under statutes which expressly limit their protection to publicly-owned areas. ${ }^{26}$ Thus, plaintiffs are frequently not able to assert proprietary or economic interests to give them standing and may be unable to identify any specific individualized injury except in the most remote fashion. For example, while it might require a strained analysis to articulate harm to any individual or group resulting from the destruction of a particular species of wildlife, there are statutes which protect a number of species and reflect a congressional determination of a public interest in their preservation. The same might be true for uninhabited areas such as the Continental Shelf. It is perhaps easier to identify harm to local communities and citizens of an area where historic sites or buildings are threatened with destruction, although there is still difficulty in identifying the direct injury to any particular group or individual flowing from that destruction. Nonetheless, there can be no doubt that the public interest is injured by inadequate consideration of the preservation of historic sites and areas. Indeed, the Congress has specifically recognized that "the historical and cultural foundations of the Nation should be preserved as a living part of our community life and development in order to give a sense of orientation to the American people" and that programs should be undertaken to "insure future generations a genuine opportunity to appreciate and enjoy the rich heritage of our Nation."27 Since the Congress has clearly extended protection to historic sites and areas and since judicial review of administrative action under those statutes was apparently intended, it would be a perversion of the statutory scheme for a court to hold that a party did not have standing because he lacked a direct personal interest. Indeed, in the Ig66 amendment to the Historic Sites Act, the Congress declared that private individuals and agencies "should continue to play a vital role" in preservation of historic areas. ${ }^{28}$ Thus, in cases involving injury to public areas, since the element of individual harm or injury is often remote, or lacking, the courts have focused not on the harm that will flow to the particular plaintiffs, but instead upon whether there will be harm to the public and whether the plaintiffs will be responsible spokesmen for the public interests involved. This analysis was given support by the Supreme Court in Flast v. Cohen ${ }^{20}$ in which the

\footnotetext{
${ }^{25}$ L. Jaffe, Judicial Controt of Administrative Action 460 (I965).

${ }^{28}$ Department of Transportation Act, 49 U.S.C. $\$ 1653(f)$ (I970).

${ }^{27} 16$ U.S.C. $\$ 470(1970)$.

${ }^{28} \mathrm{x} 6$ U.S.C. $\$ 470$ (1970). However, the legislative history of the act implies that this declaration may have been intended to explain why the federal government was initiating a program of loans and grants-in-aid with respect to historic buildings. The purpose, it is suggested, was to encourage local initiative for historic preservation projects.

${ }^{20} 392$ U.S. 83 (1968).
} 
Court held for the first time that a federal taxpayer had standing, solely as a taxpayer, to challenge the constitutionality of a federal statute providing for expenditure of federal funds. In that case the economic injury to the taxpayer was miniscule, and the Court, in holding that the taxpayer had standing, seemed guided not so much by the injury to the plaintiff, but by its belief that the issues would be "framed with the necessary specificity ....." "contested with the necessary adverseness ....," and the action "pursued with the necessary vigor ...."30 When analyzed in those terms, the standing of conservation and preservation organizations and societies to pursue a bona fide action under federal statutes seems clear.

III

\section{The Restructive Concept of Standing}

It is true that not all courts have followed the liberalized doctrine of standing begun in Scenic Hudson and Church of Christ. Unfortunately, one area in which plaintiffs have had difficulty is in historic preservation cases. In Kent County Council for Historic Preservation v. Romney, ${ }^{31}$ a local historic preservation group brought suit under the Historic Sites Act of $1966,{ }^{32}$ seeking to enjoin destruction of the Old Grand Rapids City Hall on the basis that the Advisory Council on Historic Preservation was not given an opportunity to comment on the destruction. The court held against the plaintiffs on the merits because the urban renewal project had been approved long before the effective date of the Act. Ignoring cases such as Scenic Hudson, the court also held that the plaintiffs lacked any interest that would give them standing because

We are concerned with inanimate objects such as districts, sites, buildings, structures, or objects that are included in the National Register, tather than with individuals, organizations or corporations. ${ }^{33}$

The distinction which the court draws is difficult to accept. The areas and structures included in the National Register are granted protection in order that our history and heritage may be preserved for our generation and those to come. It is for the people that these buildings are to be preserved, and it is the people who will suffer if they are not. Thus, it would appear that individuals, organizations, or corporations do represent the interests protected by the statute. Because of its departure from the trend of environmental and conservation cases, it is doubtful that this case will have a significant impact in future decisions.

A second historic preservation case in which the plaintiffs were denied standing is South Hill Neighborhood Association v. Romney, ${ }^{34}$ a case also involving an

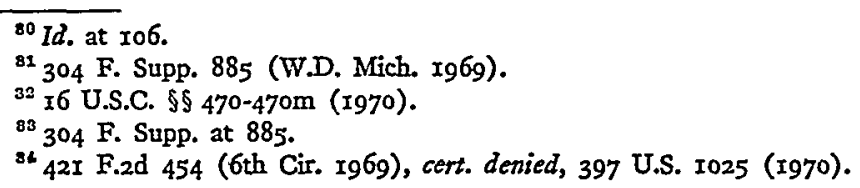


urban renewal project which called for the destruction of certain historic buildings. The plaintiffs claimed that the defendant had failed to afford the Advisory Council an opportunity for comment. The court indicated that because the plaintiffs did not own the buildings in question and had no legal control over them, they had no personal stake in the outcome of the litigation. This analysis revives the notion, generally abandoned in other cases, that an economic or proprietary interest is necessary in order for a party to have a sufficient interest in the outcome of litigation. ${ }^{35}$ The court, however, went on to hold that the plaintiffs did not have standing under the private attorney general doctrine because they had not "sufficiently engaged in the administrative process to show a special interest in the controversy ...."30 This portion of the court's analysis is more convincing. It is not unreasonable to require that if there are formal or informal administrative proceedings, a plaintiff must participate in them if he is later to seek to represent the public interest in litigation. In most environmental cases, there has been active participation by the plaintiffs in the administrative process and this requirement should not prove a serious obstacle to future litigation.

It is also perhaps relevant that in both Kent County and South Hill the courts did not confine their analysis to the plaintiff's standing, but also held that in neither case could the plaintiffs prevail on the merits. Although the issue on the merits should be kept separate from the question of standing, it seems likely that the courts' view of standing in these two cases was influenced by its view on the merits. ${ }^{37}$

The holdings in these two cases, particularly Kent County, depart significantly from the approach adopted in Scenic Hudson, Church of Christ, and their progeny, and they have not been followed in later environmental decisions. Indeed, in view of the recent Supreme Court standing decisions ${ }^{38}$ they seem destined for an early demise. There should be no distinction between the environmental and the preservation cases. Particularly in light of Congress' declaration in the Historic Sites Act that private agencies and individuals "should continue to play a vital role"30 in the preservation of historic sites and areas, it is to be hoped that the liberalized standing rules developed in the environmental cases, and not the more restrictive approaches stated in South Hill and Kent County, will govern standing in the historic preservation area.

There is a danger of unnecessary reliance on the public action concept to support the standing of plaintiffs in preservation cases. In their haste to apply Scenic Hudson and Church of Christ, both litigants and courts have, in many cases, overlooked

\footnotetext{
${ }^{85}$ See text accompanying note 51 infra.

${ }^{80} 42 x$ F.2d at $46 x$.

${ }^{87}$ In Kent County, after explaining plaintiffs' theory that the Advisory Council on Historic Preservation should have been consulted before actual expenditures were made for the urban renewal project even though it had been previously approved, the court said, "This Court would have to be mad to place such a ludicrous interpretation on the simple clear language employed by Congress in $\$ 407 f$." 304 F. Supp. at 888 .

${ }^{38}$ See text accompanying notes 47 \& 48 infra.

so 16 U.S.C. $\$ 470$ (1970).
} 
factors which would make the analysis of standing less difficult and would at least analogize these cases more closely to a traditional private action. For example, in Citizens Committee for the Hudson Valley v. Volpe, ${ }^{40}$ an action to enjoin construction of the proposed Hudson River Expressway, two plaintiffs, the Sierra Club and the Citizens Committee, apparently made no claim that the project threatened any harm to them. Thus, the court was forced to analyze the problem in terms of a public action. But in view of the organizations' substantial membership in the area and their serious concern for the natural resources there, there undoubtedly were numerous members who used the area for recreation purposes, who visited it, and whose activities in the area would be disturbed by the highway. Yet, the plaintiffs apparently did not assert the individual harm to its members as a basis for its standing. While utilization of the public interest concept is usually sufficient, it seems clear that there is a greater likelihood that standing will be found if a group can identify a particular harm to its members, even though it may be shared by others. In Citizens Committee for the Hudson Valley, the failure to particularize the harm to the plaintiff's members did not alter the result since the court held that the groups had standing. However, in Sierra Club v. Hickel, ${ }^{41}$ the Court of Appeals for the Ninth Circuit held that the Sierra Club did not have standing in an action against a large scale commercial and recreational development in the Mineral King Valley and the Sequoia National Forest. The court construed the complaint as alleging only that the "actions are personally displeasing or distasteful"42 to the members of the Sierra Club. Apparently there was no allegation that members of the Sierra Club used the area or that their activities would be disturbed by the project. The court did not believe that

such club concern without a showing of more direct interest can constitute standing in the legal sense sufficient to challenge the exercise of responsibilities on behalf of all the citizens by two cabinet level officials of the government acting under a Congressional and constitutional mandate. ${ }^{43}$

The court rejected any reliance upon Scenic Hudson, stating that the provisions of the Federal Power Act allowing for suits by parties aggrieved, provided the basis for standing in that case, whereas in the present case no comparable provisions existed. ${ }^{44}$ The court also distinguished Citizens Committee for the Hudson Valley on the basis that in that case residents in the area had joined the Sierra Club as plaintiffs so as to provide the requisite direct interest in administrative action. ${ }^{45}$ The court indicated that its decision may well have been different if there had been a similar joinder in the case before it. It may be that a close reading of the complaint

\footnotetext{
${ }^{10} 425$ F.2d 97 (2d Cir. I970), cert. denied, 400 U.S. 949 (I97I).

4233 F.2d 24 (9th Cir. 1970), cert. granted 40 I U.S. 907 (I97x).

${ }^{2}$ Id. at 33 .

${ }^{18} \mathrm{Id}$. at 30 .

"Id.

sI Id. at 33 .
} 
would disclose sufficient harm to sustain standing. The plaintiffs, however, could have helped their case by a particularized allegation of injury. ${ }^{46}$

\section{IV}

\section{Tre Data Processing and Barlow Decisions}

In I970, the Supreme Court decided two standing cases which, although not directly in point for the standing issues under consideration here, should make it easier for plaintiffs in preservation and conservation cases to bring themselves within the traditional scope of a private action. ${ }^{47}$ In Data Processing Service v. Camp, the Court held that an organization of companies selling data processing services had standing to challenge a ruling by the Comptroller of the Currency permitting banks to make available data processing services to other banks and bank customers. The Court substituted for the legal interest test, which had been widely used to determine standing, a two-fold test. The first test is "whether the plaintiff alleges that the challenged action has caused him injury in fact, economic or otherwise."48 The second test is "whether the interest sought to be protected by the complainant is arguably within the zone of interests to be protected or regulated by the statute or constitutional guarantee in question." ${ }^{49}$ In that case the plaintiffs had been injured "in fact" because the ruling under review would result in increased competition to the plaintiffs for sale of data processing services. In Barlow v. Collins, a companion case, the Court held that tenant farmers had standing to challenge a regulation of the Secretary of Agriculture which broadened the purposes for which government benefit payments to the farmers could be assigned. The plaintiffs suffered injury from this regulation because it permitted their landlords to demand that they assign their benefits as a condition of working the land. In both cases the Court found that the rights asserted were "arguably within the zone of interests" protected by the statutes on which the plaintiffs relied.

It is perhaps too early to determine the effect of these decisions on the standing of groups in conservation and preservation cases. Citing Scenic Hudson and Church of Christ, the Court stated in Data Processing Service v. Camp that the interests of the plaintiff which may be protected are not limited to economic interests but "may reflect aesthetic, conservational, and recreational ... values."50 Thus, if an individual or a group shows "injury in fact" to an aesthetic, conservation, or recreational interest, it will have standing under these decisions to bring a private action and there will be no need to rely on the theory that the party is suing as a private

\footnotetext{
${ }^{\$ 3}$ After holding that the Sierra Club did not allege sufficient injury to give it standing, the court also held that the Club could not sue as a private attorney general because it could "find no indication in any federal statute that Congress had 'conferred' on the Sierra Club or any group like it, authority to bring suits to challenge official action." 433 at 33 n.9.

${ }^{47}$ Data Processing Service v. Camp, 397 U.S. I50 (1970); Barlow v. Collins, 397 U.S. 159 (1970).

${ }^{48} 397$ U.S. at 152.

6 Id. at 153 .

${ }^{50}$ Id. at I54.
} 
attorney general. Even if the plaintiff cannot identify injury in fact to himself, however, he may still have standing to represent the public interest if he can meet the "special interest" test of Scenic Hudson."

\section{ConcLusion}

How are we to assess the recent developments in the law of standing? Initially, it appears that the relaxation of standing requirements has not resulted in any of the dire consequences sometimes predicted by those who favor more restrictive tests. The courts have not been flooded with an unmanageable amount of litigation; dockets are no more clogged than ever. Courts have not been propelled into resolution of abstract or hypothetical controversies nor, can one fairly say, have they been called upon to make judgments beyond their competence. Rather, the judiciary has helped to ensure that the legislation is administered in the spirit in which it was enacted. Indeed, active participation by the judiciary is essential to make this legislation effective. The impact of these statutes depends in large measure on day-to-day administration, and in many cases the agencies which initially created the problems to which the laws are addressed are charged with that administration. For example, section $4(f)$ of the Department of Transportation Act ${ }^{52}$ was passed because of the Bureau of Public Roads' lack of concern for the natural and historic resources which stood in the path of federal aid highways. Yet, it is the Bureau and the Secretary of Transportation which administer that Act. The likelihood of judicial review of administrative action under statutes such as section $4(f)$ can play a large role in ensuring that administrators adjust their regulatory philosophy to comply fully with new legislation. A second factor which makes judicial review essential is that in many instances strong economic and political pressures are exerted on the administrative process, and those forces have in the past often shut out serious consideration of environmental values. Judicial review provides one of the best means for ensuring that these influences do not frustrate the protection of environmental interests required by the new legislation.

Thus, the judiciary has a vital role to play in assuring faithful administration of statutes such as section $4(f)$ and the Historic Sites Act. It is appropriate that concomitantly with the enactment of these statutes and the growing public and private concern with the protection of the environment, the courts have liberalized the doctrine of standing so that it no longer looms as a major obstacle to environmental and conservation litigation.

\footnotetext{
${ }^{51}$ In Data Processing Service and Barlow, both Justice Douglas and Justice Brennan made it clear that they were not addressing the standing of parties to sue in cases in which the parties brought suit only to vindicate the interest of the general public. 397 U.S. at I53 n.I; 397 U.S. at I72 $\mathbf{n . 5}$ (opinion of Brennan, J.).

${ }_{42} 49$ U.S.C. $\$ 16_{53}(f)(1970)$.
} 